The

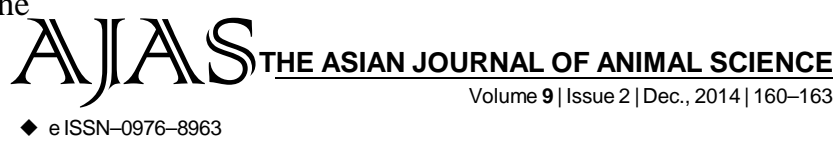

DOI : 10.15740/HAS/TAJAS/9.2/160-163 Visit us | www.researchjournal.co.in

RESEARCH ARTICLE........

\title{
Economics of goat farming under traditional low input production system in Bikaner district
}

UPENDRA KUMAR, M.L. REAGER, RANVEER SINGH, GEETA BALWADA AND DEEPAK CHATURVEDI

ABSTRACT...... The study was conducted in four blocks of Bikaner district of Rajasthan. Three villages selected from each block and ten farmers selected from each village. Total 120 farmers selected for data collection on different flock sizes were undertaken to evaluate the economic performance of goats under traditional farming system. Study revealed that small flock size (5-10) was most profitable followed by 10-25 and 25-50. The net return worked out to be Rs. 6895,6650 and 6492 per goat/annum, respectively. The net profit (per goat/annum) decreased linearly with the increase of flock sizes due to inadequate nutrition and management practices by larger goat keepers. Sell of goats was the major source of income $(49.93 \%)$ followed by milk $(41.85 \%)$ and manures $(4.20 \%)$. Therefore, rearing of goat cannot

Author for Corresponding UPENDRA KUMAR Krishi Vigyan Kendra (S.K.A.U.), BIKANER (RAJASTHAN) INDIA

Email: ukmeel@gmail.com

See end of the article for

Coopted authors' sustain only on grazing resources, needs to switch over to semi-intensive/ intensive system of management.

KEY WORDS...... Goat farming; Economics of goat farming

HOW TO CITE THIS ARTICLE - Kumar, Upendra, Reager, M.L., Singh, Ranveer, Balwada, Geeta and Chaturvedi, Deepak (2014). Economics of goat farming under traditional low input production system in Bikaner district. Asian J. Animal Sci., 9(2) : 160-163.

ARTICLE CHRONICLE - Received : 28.08.2014; Revised : 05.11.2014; Accepted : 20.11.2014 